CATÃO, HCRM; GOMES, LAA; GUIMARÃES, RM; FONSECA, PHF; CAIXETA, F; GALVÃO, AG. 2018. Physiological and biochemical changes in lettuce seeds during storage at different temperatures. Horticultura Brasileira 36: 118-125. DOI - http://dx.doi.org/10.1590/S0102-053620180120

\title{
Physiological and biochemical changes in lettuce seeds during storage at different temperatures
}

\section{Hugo Cesar RM Catão; Luiz Antonio Augusto Gomes; Renato M Guimarães; Pedro Henrique F Fonseca; Franciele Caixeta; Alexandre G Galvão}

Universidade Federal de Lavras (UFLA), Lavras-MG, Brazil; hugocatao@yahoo.com.br; laagomes@dag.ufla.br; renatomg@dag.ufla.br; pedro_fonseca90@hotmail.com; francielecaixeta@yahoo.com.br; galvao.alexandre@hotmail.com

\begin{abstract}
Dormancy in lettuce seeds is a process not yet fully understood. High storage temperatures can cause seed dormancy promoting physiological and enzymatic changes. The goal of this study was to investigate the influence of storage period and environments on the quality and dormancy of different lettuce cultivars. We also investigated the biochemical changes. A completely randomized experimental design was used in a $4 \times 8 \times 3$ factorial arrangement to evaluate physiological quality on different storage periods $(30,60$, 90 and 120 days) and environments $\left(15,25\right.$ and $\left.35^{\circ} \mathrm{C}\right)$ of seeds from eight lettuce cultivars (Everglades, Babá de Verão, Elisa, Luiza, Grand Rapids, Hortência, Salinas 88 and Rubete). The biochemical activity was accessed by tetrazolium test and the activity of the endo- $\beta$-mannanase. There occurred physiological and biochemical changes on lettuce seeds under periods and high temperature storage environments. A reduction of seed quality occurred at high storage temperatures mainly when stored during 120 days. The storage period up to six months maintains the viability and vigor of lettuce seeds, when stored at $15^{\circ} \mathrm{C}$. Germination is compromised when seeds are stored over 60 days on temperatures over $25^{\circ} \mathrm{C}$. Everglades is a tolerant cultivar to germination conditions of $35^{\circ} \mathrm{C}$ and maintains its quality during storage at $15^{\circ} \mathrm{C}$. Temperatures over $25^{\circ} \mathrm{C}$ induce thermodormancy on lettuce seeds during storage. The tetrazolium test indicates that the seeds were viable; nevertheless, there was no germination at high temperatures. Enzymatic changes occurred in seeds stored at $35^{\circ} \mathrm{C}$ due to dormancy. There was a decrease in the expression of endo- $\beta$-mannanase enzyme being influenced by the environment and storage period. The Everglades cultivar is thermotolerant.
\end{abstract}

Keywords: Lactuca sativa, thermotolerance, thermoinhibition, dormancy, enzymatic activity.

\section{RESUMO}

Alterações fisiológicas e bioquímicas em sementes de alface durante $o$ armazenamento em diferentes temperaturas

Dormência em sementes de alface é um processo que ainda não está totalmente compreendido. As altas temperaturas de armazenamento podem causar dormência das sementes e promover mudanças fisiológicas e enzimáticas. O objetivo deste trabalho foi verificar a influência dos períodos e dos ambientes de armazenamento na qualidade e dormência de sementes de diferentes cultivares de alface e investigar as alterações bioquímicas. O delineamento experimental foi inteiramente casualizado, em esquema fatorial $4 \times 8 \times 3$ para avaliar a qualidade fisiológica de oito cultivares de alface (Everglades, Babá de Verão, Elisa, Luiza, Grand Rapids, Hortência, Salinas 88 e Rubete) em diferentes períodos (30, 60, 90 e 120 dias) e ambientes de armazenamento $\left(15,25\right.$ e $\left.35^{\circ} \mathrm{C}\right)$. A atividade bioquímica foi avaliada pelo teste de tetrazólio e pela a atividade da endo- $\beta$-mananase. Há alterações fisiológicas e bioquímicas nas sementes de alface em virtude do período e do ambiente de armazenamento em altas temperaturas. Há uma redução da qualidade das sementes a temperaturas elevadas de armazenamento, principalmente aos 120 dias. Verificou-se que o período de armazenamento até os seis meses mantém a viabilidade e vigor de sementes de alface, quando armazenadas a $15^{\circ} \mathrm{C}$. As sementes armazenadas em ambientes com temperatura superior a $25^{\circ} \mathrm{C}$ não toleram o armazenamento a partir de 60 dias o que compromete a germinação e o vigor. A cultivar Everglades é tolerante à condição de germinação a $35^{\circ} \mathrm{C}$ e mantém sua qualidade ao longo do armazenamento em temperatura de $15^{\circ} \mathrm{C}$. A temperatura acima de $25^{\circ} \mathrm{C}$ induz à termodormência das sementes nas cultivares de alface durante o armazenamento. O teste de tetrazólio indica que as sementes estavam viáveis, contudo não houve germinação em temperaturas elevadas. Ocorrem alterações enzimáticas nas sementes armazenadas em temperatura de $35^{\circ} \mathrm{C}$ devido à dormência. Houve decréscimo na expressão da enzima endo- $\beta$-mananase, sendo influenciada pelo ambiente e período de armazenamento. A cultivar Everglades é termotolerante.

Palavras-chave: Lactuca sativa, termotolerância, termoinibição, dormência, atividade enzimática.

Received on September 30, 2016; accepted on May 29, 2017

$\mathrm{L}$ ettuce (Lactuca sativa) is the most important leafy vegetable in the Brazilian diet (Nascimento et al., 2012). It is cultivated throughout the year in different regions and under different edaphic and climatic conditions. High temperatures are highly influential on germination of lettuce seeds and may lead to seed dormancy due to hardening of the endosperm, which ends up restricting radicle protrusion (Nascimento et al., 2012). Silva et al. 
(2004) claim that, when seeds have germination limited by the endosperm, this tissue must be weakened to allow radicle protrusion, and this is the role of enzymes such as endo- $\beta$-mannanase. The endosperm cell wall in lettuce seeds consists mainly of galactomannans, and the endo- $\beta$-mannanase enzyme is part of the mechanism that degrades it (Nascimento et al., 2012). Increased activity of this enzyme in cultivars germinated at high temperatures is related to seed thermotolerance (Catão et al., 2014).

The ambient conditions for storage, such as air temperature and relative humidity, are preponderant factors for conservation of seeds until planting (Carvalho \& Pinho, 2000). After planting, lettuce producers store packages containing remaining seeds in inappropriate locations, where ambient temperature is usually high, realizing later, at the following planting period, that seed quality was compromised. Thus dormancy in lettuce seeds is not well-understood process, and it is not known if it is acquired during storage at high temperatures.

High temperature, in addition to cause dormancy in lettuce seeds, also accelerates chemical reactions and intensifies metabolic processes. As a consequence of these metabolic events, seed respiration is greater, which leads to an increase in speed of deterioration.

The tetrazolium test is a quick biochemical test able to detect seed viability based on seed respiration, particularly in species which are slow to germinate and exhibit dormancy. The test is based on color change of living tissue in the presence of a tetrazolium solution. This color change reflects the activity of dehydrogenase enzymes involved in seed respiration. These enzymes, particularly malic acid dehydrogenase, catalyze the reaction of $\mathrm{H}^{+}$ions released by the reaction of living tissue with the salt (2,3,5-triphenyl tetrazolium chloride) to form a red-colored substance called trifenilformazan, which is stable and non-diffusible.

In the process of seed deterioration, one of the first degradation events is loss of membrane permeability. The membrane loses its selectivity and the enzymes and proteins become less efficient in catalytic activities (Smith \& Berjak, 1995). Some of these enzymes and proteins may be used to measure seed quality (vigor), even when there is a fall in reserves during storage at high temperatures (Marcos Filho, 2005). Knowledge of the physiological and biochemical quality of the seeds may clarify if dormancy in lettuce seeds may be acquired during storage. The goal of this study was to verify the influence of storage period and environment conditions on the physiological and biochemical quality and dormancy of seeds of different lettuce cultivars.

\section{MATERIAL AND METHODS}

The production process of lettuce seeds was conducted in an experimental area in the municipality of Lavras, Minas Gerais State, Brazil ( $21^{\circ} 14^{\prime} 24^{\prime \prime} \mathrm{S}$, $45^{\circ} 00^{\prime} 34^{\prime \prime} \mathrm{W}$ ), where the soil is classified as an Oxisol with a clayey texture.

Initially, seedlings were produced from different lettuce cultivars: Everglades, Babá de Verão, Elisa, and Luiza (smooth leaf), Grand Rapids and Hortência (curly leaf), and Salinas 88 and Rubete (crisp head). They were sown in 128-cell expanded polystyrene trays containing a commercial substrate for vegetable seedlings. After 21 days, the seedlings were transplanted in seedbeds in a protected growth area. Each plot had 6 plants in one row, spaced $0.4 \mathrm{~m}$ apart in the row and 0.6 $\mathrm{m}$ between rows, summarizing $7.2 \mathrm{~m}^{2}$ of area, following a randomized block design with three replications; looking for minimizing potential environmental effects during seed formation. During the seed production process the maximum and minimum mean temperatures of the air measured at $1.5 \mathrm{~m}$ from the soil were 45 and $31^{\circ} \mathrm{C}$, respectively. Seeds of each plant from the same cultivar were harvested individually within each block and then mixed uniformly, composing a single seed lot.

Subsequently, seeds were treated with a carboxin fungicide before storage. The product was manually applied to the seeds in semi-impermeable plastic bags of a neutral chemical composition, and shaken until complete distribution. Before carrying out the tests, the seeds of the different cultivars were subjected to determination of moisture content and evaluation was performed according to the Rules for Seed Analysis (RAS) (Brasil, 2009) and the results were expressed in percentage.

Later, seeds from each cultivar were homogenized, placed in individual Kraft paper bags and stored in BOD chambers for a period of $30,60,90$ and 120 days under temperatures of 15, 25 and $35^{\circ} \mathrm{C}$. Physiological and biochemical quality were evaluated in each storage/ temperature regimen.

For the germination test, seeds were put between two blotting paper sheets, moistened with water at the proportion of 2.5 times the weight of the dry substrate, in gerbox type plastic boxes. The boxes with the seeds were kept in BOD type chambers under an alternating light and temperature regimen, 12 hours in the dark and 12 hours in the presence of light at 20 and $35^{\circ} \mathrm{C}$, respectively. Four subsamples of 50 seeds from each cultivar were analyzed.

The tetrazolium test was carried out on the remaining seeds (seeds that did not germinate) from the germination test, with the seed coats being removed and the embryos subjected to the test. Seeds were stained in a solution of 2,3,5-triphenyl tetrazolium chloride at a concentration of $1 \%$ during 3 hours in the dark at $30^{\circ} \mathrm{C}$. After this period, having checked the staining, the embryos were washed in running water and kept submersed in water until their evaluation, when they were individually analyzed to verify their viability. Interpretation was made according to RAS (Brasil, 2009), and the results were expressed in percentage of viable seeds.

To evaluate the emergence, four replications of 50 seeds of each cultivar were used, distributed in multicell polystyrene trays containing the commercial substrate Multiplant for vegetables. The trays were kept in a greenhouse equipped with an intermittent mist system. Daily evaluations were made since the beginning of emergence, computing the number of emerged 
seedlings up to stabilization of stand (Queiroz et al., 2011).

For the enzyme endo- $\beta$-mannanase, the lettuce seeds from each treatment were placed to soak in plastic boxes on blotting paper moistened with distilled water at a quantity equivalent to 2.5 times the weight of the dry substrate. The seeds were kept in a germinator at $20^{\circ} \mathrm{C}$ during 24 hours and, after soaking, 150 seeds of each cultivar were macerated in a crucible with liquid nitrogen and polyvinylpyrrolidone (PVP). In each microtube, with $100 \mathrm{mg}$ of powder from each sample, $300 \mu \mathrm{L}$ of extraction buffer [0.1 M Hepes/0.5 $\mathrm{M} \mathrm{NaCl}$ and ascorbic acid (5 $\mathrm{mg}$ of ascorbic acid per $\mathrm{mL}$ of buffer), $\mathrm{pH}$ 8.0] were added. The microtubes were then centrifuged during 30 minutes at $12,000 \mathrm{~g}$ and $2 \mu \mathrm{L}$ of the supernatant were applied in gel containing $6 \mathrm{~mL}$ of LBG (Locust Bean Gum), $0.24 \mathrm{~g}$ of agarose, and $24 \mathrm{~mL}$ of buffer $\mathrm{pH} 5.0$ (1 $M$ citric acid/ $0.4 \mathrm{M}$ of $\mathrm{Na}_{2} \mathrm{HPO}_{4} 2 \mathrm{H}_{2} \mathrm{O}$ ). The aliquots were applied in $2 \mathrm{~mm}$ holes made in the gel with the aid of an awl. The gel was incubated during $21 \mathrm{~h}$ in refrigerated conditions and revealed according to the methodology proposed by Silva et al. (2004). The activity of the enzyme endo- $\beta$-mannanase was calculated according to Downie et al. (1994).

In the test for evaluation of physiological quality of the lettuce seeds, we used a completely randomized experimental design in a $4 \times 8 \times 3$ factorial arrangement, whose factors were four storage periods $(30,60,90$, and 120 days), eight lettuce cultivars, and three storage environments $(15,25$, and $35^{\circ} \mathrm{C}$ ). Then analysis of variance was performed at $5 \%$ probability by the $\mathrm{F}$
Test. For the comparison of means, the Scott-Knott test was used, at 5\% probability.

\section{RESULTS AND DISCUSSION}

The moisture content of the seeds after drying ranged from 5 to $6 \%$, values also reported by Barbosa et al. (2011) in different lettuce seed lots. Based on analysis of variance, significant differences were observed among the cultivars, storage periods, and storage environments, just as for interaction among the factors $(p<0.05)$. The mean values of germination (\%) at 20 and $35^{\circ} \mathrm{C}$ of the seeds of lettuce cultivars stored in different environments are shown in Table 1.

For germination at $20^{\circ} \mathrm{C}$ (Table 1), regardless of the storage period, the

Table 1. Germination (\%) at 20 and $35^{\circ} \mathrm{C}$ of seeds from eight lettuce cultivars depending on ambient temperatures and storage periods. Lavras, UFLA, 2015.

\begin{tabular}{|c|c|c|c|c|c|c|c|c|c|c|c|c|}
\hline \multirow{5}{*}{ Cultivars } & \multicolumn{12}{|c|}{ Germination $\left(20^{\circ} \mathrm{C}\right)$} \\
\hline & \multicolumn{12}{|c|}{ Storage periods (days) } \\
\hline & \multicolumn{3}{|c|}{30} & \multicolumn{3}{|c|}{60} & \multicolumn{3}{|c|}{90} & \multicolumn{3}{|c|}{120} \\
\hline & & & & \multicolumn{6}{|c|}{ Storage temperatures $\left({ }^{\circ} \mathrm{C}\right)$} & & & \\
\hline & 15 & 25 & 35 & 15 & 25 & 35 & 15 & 25 & 35 & 15 & 25 & 35 \\
\hline Luiza & $94 \mathrm{Ba}$ & $94 \mathrm{Ba}$ & $81 \mathrm{Cb}$ & $91 \mathrm{Ba}$ & $89 \mathrm{Ba}$ & $80 \mathrm{Bb}$ & $91 \mathrm{Ba}$ & $86 \mathrm{Bb}$ & $75 \mathrm{Bc}$ & $90 \mathrm{Ba}$ & $82 \mathrm{Ab}$ & $69 \mathrm{Bc}$ \\
\hline Elisa & $84 \mathrm{Ca}$ & $82 \mathrm{Ca}$ & $76 \mathrm{Db}$ & $84 \mathrm{Ca}$ & $75 \mathrm{Db}$ & $68 \mathrm{Cc}$ & $80 \mathrm{Ca}$ & $76 \mathrm{Ca}$ & $63 \mathrm{Cb}$ & $81 \mathrm{Ca}$ & $70 \mathrm{Bb}$ & $59 \mathrm{Cc}$ \\
\hline G. Rapids & $96 \mathrm{Aa}$ & $92 \mathrm{Ba}$ & $70 \mathrm{~Eb}$ & $95 \mathrm{Aa}$ & $73 \mathrm{Db}$ & $53 \mathrm{Ec}$ & $90 \mathrm{Ba}$ & $51 \mathrm{~Eb}$ & $28 \mathrm{Ec}$ & $88 \mathrm{Ba}$ & $42 \mathrm{Db}$ & $15 \mathrm{Ec}$ \\
\hline B. Verão & $96 \mathrm{Aa}$ & $93 \mathrm{Ba}$ & $70 \mathrm{~Eb}$ & $95 \mathrm{Aa}$ & $83 \mathrm{Cb}$ & $60 \mathrm{Dc}$ & $89 \mathrm{Ba}$ & $80 \mathrm{Cb}$ & $60 \mathrm{Cc}$ & $90 \mathrm{Ba}$ & $51 \mathrm{Cb}$ & $32 \mathrm{Dc}$ \\
\hline Hortência & $97 \mathrm{Aa}$ & $94 \mathrm{Ba}$ & $88 \mathrm{Bb}$ & $94 \mathrm{Aa}$ & $76 \mathrm{Db}$ & 62Dc & $91 \mathrm{Ba}$ & $63 \mathrm{Db}$ & $50 \mathrm{Dc}$ & $88 \mathrm{Ba}$ & $22 \mathrm{~Eb}$ & $11 \mathrm{Fc}$ \\
\hline Rubete & $98 \mathrm{Aa}$ & $78 \mathrm{Cb}$ & $60 \mathrm{Fc}$ & $96 \mathrm{Aa}$ & $64 \mathrm{~Eb}$ & $44 \mathrm{Fc}$ & $94 \mathrm{Aa}$ & $51 \mathrm{~Eb}$ & $21 \mathrm{Fc}$ & $91 \mathrm{Ba}$ & $19 \mathrm{~Eb}$ & $9 \mathrm{Fc}$ \\
\hline Salinas 88 & $92 \mathrm{Ba}$ & $89 \mathrm{Ba}$ & $70 \mathrm{~Eb}$ & $88 \mathrm{Ba}$ & $59 \mathrm{Fb}$ & $44 \mathrm{Fc}$ & $89 \mathrm{Ba}$ & $51 \mathrm{~Eb}$ & $18 \mathrm{Fc}$ & $85 \mathrm{Ca}$ & $17 \mathrm{~Eb}$ & $12 \mathrm{Fc}$ \\
\hline Everglades & $99 \mathrm{Aa}$ & $100 \mathrm{Aa}$ & $99 \mathrm{Aa}$ & $98 \mathrm{Aa}$ & 99Aa & 99Aa & $96 \mathrm{Aa}$ & $92 \mathrm{Ab}$ & $90 \mathrm{Ab}$ & $97 \mathrm{Aa}$ & $83 \mathrm{Ab}$ & $84 \mathrm{Ab}$ \\
\hline \multirow[t]{2}{*}{ CV (\%) } & \multicolumn{12}{|c|}{3.89} \\
\hline & \multicolumn{12}{|c|}{ Germination $\left(35^{\circ} \mathrm{C}\right)$} \\
\hline Luiza & $94 \mathrm{Ba}$ & $94 \mathrm{Ba}$ & $81 \mathrm{Cb}$ & $91 \mathrm{Ba}$ & $89 \mathrm{Ba}$ & $80 \mathrm{Bb}$ & $91 \mathrm{Ba}$ & $86 \mathrm{Bb}$ & $75 \mathrm{Bc}$ & $90 \mathrm{Ba}$ & $82 \mathrm{Ab}$ & $69 \mathrm{Bc}$ \\
\hline Elisa & $84 \mathrm{Ca}$ & $82 \mathrm{Ca}$ & $76 \mathrm{Db}$ & $84 \mathrm{Ca}$ & $75 \mathrm{Db}$ & $68 \mathrm{Cc}$ & $80 \mathrm{Ca}$ & $76 \mathrm{Ca}$ & $63 \mathrm{Cb}$ & $81 \mathrm{Ca}$ & $70 \mathrm{Bb}$ & $59 \mathrm{Cc}$ \\
\hline G. Rapids & $96 \mathrm{Aa}$ & $92 \mathrm{Ba}$ & $70 \mathrm{~Eb}$ & $95 \mathrm{Aa}$ & $73 \mathrm{Db}$ & $53 \mathrm{Ec}$ & $90 \mathrm{Ba}$ & $51 \mathrm{~Eb}$ & $28 \mathrm{Ec}$ & $88 \mathrm{Ba}$ & $42 \mathrm{Db}$ & $15 \mathrm{Ec}$ \\
\hline B. Verão & $96 \mathrm{Aa}$ & $93 \mathrm{Ba}$ & $70 \mathrm{~Eb}$ & $95 \mathrm{Aa}$ & $83 \mathrm{Cb}$ & 60Dc & $89 \mathrm{Ba}$ & $80 \mathrm{Cb}$ & $60 \mathrm{Cc}$ & $90 \mathrm{Ba}$ & $51 \mathrm{Cb}$ & $32 \mathrm{Dc}$ \\
\hline Hortência & $97 \mathrm{Aa}$ & $94 \mathrm{Ba}$ & $88 \mathrm{Bb}$ & $94 \mathrm{Aa}$ & $76 \mathrm{Db}$ & $62 \mathrm{Dc}$ & $91 \mathrm{Ba}$ & $63 \mathrm{Db}$ & $50 \mathrm{Dc}$ & $88 \mathrm{Ba}$ & $22 \mathrm{~Eb}$ & $11 \mathrm{Fc}$ \\
\hline Rubete & $98 \mathrm{Aa}$ & $78 \mathrm{Cb}$ & $60 \mathrm{Fc}$ & $96 \mathrm{Aa}$ & $64 \mathrm{~Eb}$ & $44 \mathrm{Fc}$ & $94 \mathrm{Aa}$ & $51 \mathrm{~Eb}$ & $21 \mathrm{Fc}$ & $91 \mathrm{Ba}$ & $19 \mathrm{~Eb}$ & $9 \mathrm{Fc}$ \\
\hline Salinas 88 & $92 \mathrm{Ba}$ & $89 \mathrm{Ba}$ & $70 \mathrm{~Eb}$ & $88 \mathrm{Ba}$ & $59 \mathrm{Fb}$ & $44 \mathrm{Fc}$ & $89 \mathrm{Ba}$ & $51 \mathrm{~Eb}$ & $18 \mathrm{Fc}$ & $85 \mathrm{Ca}$ & $17 \mathrm{~Eb}$ & $12 \mathrm{Fc}$ \\
\hline Everglades & $99 \mathrm{Aa}$ & $100 \mathrm{Aa}$ & $99 \mathrm{Aa}$ & $98 \mathrm{Aa}$ & $99 \mathrm{Aa}$ & 99Aa & $96 \mathrm{Aa}$ & $92 \mathrm{Ab}$ & $90 \mathrm{Ab}$ & $97 \mathrm{Aa}$ & $83 \mathrm{Ab}$ & $84 \mathrm{Ab}$ \\
\hline
\end{tabular}

Mean values followed by the same uppercase letter in the column and lowercase letter in the row do not differ among themselves by the Scott-Knott Test at 5\% probability. 
Table 2. Viable (\%) (V) and dead (\%) (D) seeds remaining (not germinated), after 30, 60, 90 and 120 days of storage, by the tetrazolium test at $20^{\circ} \mathrm{C}$ of lettuce seeds stored at different ambient temperatures (A). Lavras, UFLA, 2015.

\begin{tabular}{|c|c|c|c|c|c|c|c|c|c|c|c|c|c|}
\hline \multirow{2}{*}{ Cultivars } & \multirow{2}{*}{$\begin{array}{c}\mathbf{A} \\
\left({ }^{\circ} \mathbf{C}\right)\end{array}$} & \multirow{2}{*}{$\mathbf{N}$} & \multicolumn{2}{|c|}{30} & \multirow{2}{*}{$\mathbf{N}$} & \multicolumn{2}{|c|}{60} & \multirow{2}{*}{$\mathbf{N}$} & \multicolumn{2}{|c|}{90} & \multirow{2}{*}{$\mathbf{N}$} & \multicolumn{2}{|c|}{120} \\
\hline & & & $\mathbf{V}$ & D & & $\mathbf{V}$ & D & & $\mathbf{V}$ & D & & $\mathbf{V}$ & D \\
\hline Luiza & 15 & 12 & 25 & 75 & 18 & 22 & 78 & 18 & 39 & 61 & 20 & 30 & 70 \\
\hline Elisa & 15 & 32 & 31 & 69 & 32 & 19 & 81 & 40 & 13 & 88 & 38 & 42 & 58 \\
\hline Grand Rapids & 15 & 8 & 0 & 100 & 10 & 40 & 60 & 20 & 45 & 55 & 24 & 38 & 63 \\
\hline Babá Verão & 15 & 8 & 38 & 63 & 10 & 30 & 70 & 22 & 41 & 59 & 20 & 35 & 65 \\
\hline Hortência & 15 & 6 & 0 & 100 & 12 & 33 & 67 & 18 & 39 & 61 & 24 & 38 & 63 \\
\hline Rubete & 15 & 4 & 25 & 75 & 8 & 13 & 88 & 12 & 33 & 67 & 18 & 39 & 61 \\
\hline Salinas 88 & 15 & 16 & 25 & 75 & 24 & 42 & 58 & 22 & 36 & 64 & 30 & 43 & 57 \\
\hline Everglades & 15 & 2 & 0 & 100 & 4 & 25 & 75 & 8 & 25 & 75 & 6 & 33 & 67 \\
\hline Luiza & 25 & 12 & 58 & 42 & 26 & 73 & 27 & 28 & 61 & 39 & 36 & 67 & 33 \\
\hline Elisa & 25 & 36 & 69 & 31 & 50 & 64 & 36 & 48 & 65 & 35 & 60 & 60 & 40 \\
\hline Grand Rapids & 25 & 16 & 81 & 19 & 54 & 83 & 17 & 98 & 73 & 27 & 116 & 68 & 32 \\
\hline Babá Verão & 25 & 14 & 79 & 21 & 34 & 56 & 44 & 40 & 58 & 43 & 98 & 64 & 36 \\
\hline Hortência & 25 & 12 & 75 & 25 & 48 & 58 & 42 & 74 & 61 & 39 & 156 & 62 & 38 \\
\hline Rubete & 25 & 44 & 59 & 41 & 72 & 61 & 39 & 98 & 77 & 23 & 162 & 64 & 36 \\
\hline Salinas 88 & 25 & 22 & 64 & 36 & 82 & 70 & 30 & 98 & 66 & 34 & 166 & 61 & 39 \\
\hline Everglades & 25 & 0 & 100 & 0 & 2 & 100 & 0 & 16 & 75 & 25 & 34 & 65 & 35 \\
\hline Luiza & 35 & 38 & 61 & 39 & 40 & 63 & 38 & 50 & 76 & 24 & 62 & 66 & 34 \\
\hline Elisa & 35 & 48 & 58 & 42 & 64 & 69 & 31 & 74 & 76 & 24 & 82 & 57 & 43 \\
\hline Grand Rapids & 35 & 60 & 82 & 18 & 94 & 82 & 18 & 144 & 83 & 17 & 170 & 77 & 23 \\
\hline Babá Verão & 35 & 60 & 88 & 12 & 80 & 76 & 24 & 80 & 61 & 39 & 136 & 63 & 38 \\
\hline Hortência & 35 & 24 & 88 & 13 & 76 & 64 & 36 & 100 & 72 & 28 & 178 & 72 & 28 \\
\hline Rubete & 35 & 80 & 63 & 38 & 112 & 65 & 35 & 158 & 87 & 13 & 182 & 69 & 31 \\
\hline Salinas 88 & 35 & 80 & 85 & 15 & 112 & 71 & 29 & 164 & 85 & 15 & 176 & 70 & 30 \\
\hline Everglades & 35 & 2 & 0 & 100 & 2 & 100 & 0 & 20 & 85 & 15 & 32 & 63 & 38 \\
\hline
\end{tabular}

'N= not germinated seeds from a total of 200 seeds

ambient temperature of $15^{\circ} \mathrm{C}$ conserved the seed quality of all the cultivars. The lettuce seeds are not affected by external factors when cold stored and this contributes to reduce the speed of deterioration processes (Nascimento et al., 2012). Regarding seeds stored at $25^{\circ} \mathrm{C}$, we observed that 60 days of storage compromised the seed quality, except for the cultivars Everglades, Luiza, and Babá de Verão, which exhibited the greatest germination percentages, with values over $80 \%$, a value considered as the minimum for commercialization of lettuce seeds (Brasil, 1986). Nevertheless, at 120 days of storage at $25^{\circ} \mathrm{C}$ we observed a decrease in germination of the cultivar Babá de Verão, and viability was reduced to $51 \%$. Thus, only the cultivars
Everglades and Luiza met the minimum standards for commercialization (Table 1) when stored at this temperature during 120 days. Increasing the storage temperature from 25 to $35^{\circ} \mathrm{C}$, there was interference in the viability of the seeds of all the lettuce cultivars, except for the cultivar Everglades (Table 1). According to Martins \& Lago (2008), high storage temperature has great influence on seed conservation, affecting the biochemical reactions that regulate seed metabolism.

As may be observed, high storage temperature greatly influences germination already at 30 days; only the cultivars Everglades, Luiza, and Hortência maintained quality under these conditions (Table 1). However, after 60 days of storage, cv. Hortência was not able to tolerate the ambient temperature of $35^{\circ} \mathrm{C}$, and cv. Luiza was not able to tolerate it after 90 storage days. Only the Everglades cultivar meets the minimum standards of commercialization after 90 days of storage, with $84 \%$ germination at $20^{\circ} \mathrm{C}$. Nascimento et al. (2012) reported that few lettuce genotypes met the minimum standards of commercialization when germinating at a high temperature. According to Nascimento et al. (2012), these standards were $98 \%, 93 \%$, and $82 \%$ for the cultivars Vitória de Verão, Camila, and Vitória Verdinha, respectively.

The storage environment at high temperature contributed to reducing seed germination of most cultivars, especially of Hortência, Rubete, and Salinas 88, which exhibited the lowest 
germination (Table 1). It may be noted that the germination of these cultivars was inhibited (thermoinhibition) when seeds were stored in a milder environment $\left(15^{\circ} \mathrm{C}\right)$ but their viability was maintained. Testing germination at $35^{\circ} \mathrm{C}$, cvs. Grand Rapids, Hortência, Babá de Verão, Rubete, and Salinas 88 exhibited a germination percentage equal to or near zero throughout the entire storage period, even when stored in a mild environment $\left(15^{\circ} \mathrm{C}\right)$ (Table 1$)$. Thermosensitive cultivars have a greater quantity of mannose and galactose in the cell wall; this causes rigidification of the endosperm and impedes root protrusion (Nascimento et al., 2001).

Germination temperature of $35^{\circ} \mathrm{C}$ assists the identification of thermotolerant cultivars, such as 'Everglades' (Catão et al., 2014). It may be observed that the seeds of this cultivar presented over $30 \%$ of germination, even when stored at $35^{\circ} \mathrm{C}$, while the germination percentage of the other cultivars was zero or near zero.
However, cv. Everglades maintained high germination throughout storage in all environments (Table 1). The Everglades seed germination decreased from $74 \%$ to $68 \%$ germination over the whole storage period, indicating its superiority in tolerating adverse conditions, as was also observed in other studies (Nascimento, 2003; Kozarewa et al., 2006). These results indicate Everglades as a potential genotype for breeding programs.

Throughout this discussion, it

Table 3. Viable (\%) (V) and dead (\%) (D) seeds remaining (not germinated), after 30, 60, 90 and 120 days of storage, by the tetrazolium test at $35^{\circ} \mathrm{C}$ of lettuce seeds stored at different ambient temperatures (A). Lavras, UFLA, 2015.

\begin{tabular}{|c|c|c|c|c|c|c|c|c|c|c|c|c|c|}
\hline \multirow{2}{*}{ Cultivars } & \multirow{2}{*}{$\begin{array}{c}\mathrm{A} \\
\left({ }^{\circ} \mathbf{C}\right)\end{array}$} & \multirow{2}{*}{$\mathbf{N}$} & \multicolumn{2}{|c|}{30} & \multirow{2}{*}{$\mathbf{N}$} & \multicolumn{2}{|c|}{60} & \multirow{2}{*}{$\mathbf{N}$} & \multicolumn{2}{|c|}{90} & \multirow{2}{*}{$\mathbf{N}$} & \multicolumn{2}{|c|}{120} \\
\hline & & & $\mathbf{V}$ & $\mathbf{M}$ & & $\mathbf{V}$ & $\mathbf{M}$ & & $\mathbf{V}$ & $\mathbf{M}$ & & $\mathbf{V}$ & $\mathbf{M}$ \\
\hline Luiza & 15 & 156 & 57 & 43 & 156 & 79 & 21 & 164 & 76 & 24 & 162 & 55 & 45 \\
\hline Elisa & 15 & 154 & 62 & 38 & 162 & 70 & 30 & 164 & 78 & 22 & 164 & 58 & 42 \\
\hline Grand Rapids & 15 & 194 & 59 & 41 & 198 & 71 & 29 & 200 & 58 & 43 & 200 & 56 & 44 \\
\hline Babá Verão & 15 & 186 & 60 & 40 & 196 & 69 & 31 & 196 & 63 & 37 & 198 & 57 & 43 \\
\hline Hortência & 15 & 200 & 64 & 36 & 196 & 62 & 38 & 200 & 60 & 40 & 200 & 64 & 37 \\
\hline Rubete & 15 & 200 & 68 & 33 & 200 & 64 & 37 & 200 & 67 & 34 & 200 & 62 & 38 \\
\hline Salinas 88 & 15 & 200 & 59 & 42 & 200 & 67 & 34 & 200 & 68 & 32 & 200 & 61 & 39 \\
\hline Everglades & 15 & 52 & 60 & 40 & 56 & 63 & 38 & 54 & 59 & 41 & 64 & 55 & 45 \\
\hline Luiza & 25 & 168 & 62 & 38 & 176 & 72 & 28 & 194 & 64 & 36 & 198 & 61 & 39 \\
\hline Elisa & 25 & 166 & 69 & 31 & 178 & 61 & 39 & 190 & 66 & 34 & 198 & 62 & 38 \\
\hline Grand Rapids & 25 & 198 & 61 & 39 & 198 & 67 & 33 & 200 & 64 & 36 & 200 & 66 & 35 \\
\hline Babá Verão & 25 & 194 & 63 & 37 & 198 & 64 & 36 & 200 & 65 & 36 & 200 & 64 & 36 \\
\hline Hortência & 25 & 200 & 68 & 32 & 200 & 59 & 41 & 200 & 68 & 32 & 200 & 66 & 34 \\
\hline Rubete & 25 & 200 & 71 & 30 & 200 & 60 & 41 & 200 & 62 & 38 & 200 & 63 & 38 \\
\hline Salinas 88 & 25 & 200 & 59 & 42 & 200 & 66 & 35 & 200 & 70 & 30 & 200 & 67 & 34 \\
\hline Everglades & 25 & 66 & 59 & 41 & 74 & 68 & 32 & 90 & 62 & 38 & 120 & 54 & 46 \\
\hline Luiza & 35 & 178 & 61 & 39 & 186 & 61 & 39 & 198 & 77 & 23 & 200 & 86 & 15 \\
\hline Elisa & 35 & 182 & 63 & 37 & 184 & 64 & 36 & 200 & 80 & 21 & 200 & 89 & 11 \\
\hline Grand Rapids & 35 & 200 & 61 & 40 & 200 & 60 & 41 & 200 & 84 & 17 & 200 & 91 & 9 \\
\hline Babá Verão & 35 & 198 & 71 & 29 & 200 & 66 & 35 & 200 & 81 & 19 & 200 & 93 & 8 \\
\hline Hortência & 35 & 200 & 66 & 35 & 200 & 63 & 37 & 200 & 81 & 20 & 200 & 94 & 7 \\
\hline Rubete & 35 & 200 & 56 & 44 & 200 & 55 & 45 & 200 & 84 & 17 & 200 & 93 & 8 \\
\hline Salinas 88 & 35 & 200 & 57 & 43 & 200 & 67 & 34 & 200 & 81 & 19 & 200 & 93 & 8 \\
\hline Everglades & 35 & 120 & 62 & 38 & 122 & 57 & 43 & 130 & 65 & 35 & 134 & 72 & 28 \\
\hline
\end{tabular}

'N= not germinated seeds from a total of 200 seeds 
was mentioned several times that the temperature of germination and of the storage environment, as well as longer periods of storage compromised the quality of lettuce seeds, thus reducing their viability. According to Harrington (1972), every 5.5 degrees of decrease in temperature doubles the potential storage time. This statement is warranted upon analyzing the tetrazolium test in seeds remaining from the germination test at 20 and $35^{\circ} \mathrm{C}$ (Tables 2 and 3, respectively).

Testing germination at $20^{\circ} \mathrm{C}$, it becomes evident that the room temperatures of 25 and $35^{\circ} \mathrm{C}$ led to greater dormancy of the seeds, as they did not germinate, which may be verified by the quantity of viable seeds (Table 2). Increasing the storage period, the high ambient temperature led to a greater number of not germinated seeds, and most of these seeds were viable. For germination at $35^{\circ} \mathrm{C}$, the tetrazolium test showed that although the seeds did not germinate, they were still viable (Table 3).

The cultivars Hortência, Rubete, and Salinas 88 did not germinate after 30 days of storage, even the seeds maintained at $15^{\circ} \mathrm{C}$; however, around $60 \%$ of the seeds were still viable, as observed in Table 3. This may have occurred due to the dormancy of the lettuce seeds imposed by thermal stress. Results of studies showed that the tetrazolium and germination tests may be considered as complementary and, in combination, they allow evaluation of the physiological quality of the seeds by means of their viability (Dias \& Alves, 2008). It is important to use the two tests, tetrazolium and germination, to know the quantity of viable and dormant seeds, information essential for quality control.

In relation to the emergence test (Table 4), it is noteworthy that seeds stored during 30 days at a temperature of 25 and $35^{\circ} \mathrm{C}$ have less vigor than those stored at $15^{\circ} \mathrm{C}$. Analyzing each cultivar, it may be seen that the ambient temperature also reduced the vigor of lettuce seeds. Only cv. Everglades tolerated longer thermal stress, showing reduction in emergence after 90 days of storage at 25 and $35^{\circ} \mathrm{C}$. Comparing the cultivars, we observed that Everglades has greater vigor at high temperatures, regardless of the storage period (Table 4).

At 120 days at $35^{\circ} \mathrm{C}$, susceptible cultivars (Grand Rapids, Babá de Verão, Hortência, Rubete, and Salinas 88) exhibited a low percentage of emergence. The emergence test, upon being performed under greenhouse conditions, simulated what occur to rural producers upon storing their seeds at high temperatures. The results of this study showed that the storage temperature reduced the quality and led to dormancy (thermodormancy) of lettuce seeds.

Similar results were observed by other authors in the performance of tomato seedlings (Ferreira et al., 2013). These authors affirm that emergence and speed of emergence are affected by temperatures above $33^{\circ} \mathrm{C}$ since these temperatures affect the speed of reorganization of the cellular membranes, thus altering seed metabolism and thereby reducing the speed of seedling emergence. Seed lots also behaved in a different manner in regard to the effects of high temperatures, when they have had a different history. Moreover, the speed of deterioration of the seeds is different, and even the component parts of a single seed deteriorate at different speeds (Marcos Filho, 2005), and this interferes in the physiological potential and in the capacity to resist adverse conditions imposed at the time of germination and emergence.

In addition to the physiological alterations caused by high temperatures in the seeds, there are alterations in the protein and/or enzymatic patterns. Lettuce seeds have germination limited by the presence of the endosperm, and there is thus the need for softening of this tissue for root protrusion to occur. This role is performed by various enzymes, such as endo- $\beta$-mannanase, which is present in the endosperm in different

Table 4. Mean seedling emergence (\%) from lettuce seeds stored at different temperatures and periods. Lavras, UFLA, 2015.

\begin{tabular}{|c|c|c|c|c|c|c|c|c|c|c|c|c|}
\hline \multirow{4}{*}{ Cultivars } & \multicolumn{12}{|c|}{ Storage periods (days) } \\
\hline & \multicolumn{3}{|c|}{30} & \multicolumn{3}{|c|}{60} & \multicolumn{3}{|c|}{90} & \multicolumn{3}{|c|}{120} \\
\hline & \multicolumn{9}{|c|}{ Storage temperatures $\left({ }^{\circ} \mathrm{C}\right)$} & & & \\
\hline & 15 & 25 & 35 & 15 & 25 & 35 & 15 & 25 & 35 & 15 & 25 & 35 \\
\hline Luiza & $93 \mathrm{Aa}$ & $83 \mathrm{Cb}$ & $66 \mathrm{Cc}$ & $94 \mathrm{Aa}$ & $83 \mathrm{Bb}$ & $52 \mathrm{Bc}$ & $93 \mathrm{Ba}$ & $69 \mathrm{Cb}$ & $36 \mathrm{Cc}$ & $84 \mathrm{Ba}$ & $53 \mathrm{Cb}$ & $26 \mathrm{Bc}$ \\
\hline Elisa & $93 \mathrm{Aa}$ & $82 \mathrm{Cb}$ & $55 \mathrm{Dc}$ & $93 \mathrm{Aa}$ & $83 \mathrm{Bb}$ & $50 \mathrm{Bc}$ & $91 \mathrm{Ba}$ & $75 \mathrm{Bb}$ & $40 \mathrm{Bc}$ & $83 \mathrm{Ba}$ & $72 \mathrm{Bb}$ & $28 \mathrm{Bc}$ \\
\hline G. Rapids & $91 \mathrm{Ba}$ & $78 \mathrm{Db}$ & $65 \mathrm{Cc}$ & $89 \mathrm{Ba}$ & $75 \mathrm{Cb}$ & $47 \mathrm{Bc}$ & $87 \mathrm{Ba}$ & $68 \mathrm{Cb}$ & $30 \mathrm{Dc}$ & $80 \mathrm{Ba}$ & $54 \mathrm{Cb}$ & $8 \mathrm{Cc}$ \\
\hline B. Verão & $94 \mathrm{Aa}$ & $87 \mathrm{Bb}$ & $73 \mathrm{Bc}$ & $90 \mathrm{Ba}$ & $86 \mathrm{Bb}$ & $48 \mathrm{Bc}$ & $87 \mathrm{Ba}$ & $68 \mathrm{Cb}$ & $36 \mathrm{Cc}$ & $78 \mathrm{Ca}$ & $50 \mathrm{Db}$ & $8 \mathrm{Cc}$ \\
\hline Hortência & $90 \mathrm{Ba}$ & $83 \mathrm{Cb}$ & $58 \mathrm{Dc}$ & $88 \mathrm{Ba}$ & $84 \mathrm{Bb}$ & $40 \mathrm{Cc}$ & $83 \mathrm{Ca}$ & $69 \mathrm{Cb}$ & $30 \mathrm{Dc}$ & $82 \mathrm{Ba}$ & $53 \mathrm{Cb}$ & $4 \mathrm{Cc}$ \\
\hline Rubete & $95 \mathrm{Aa}$ & $74 \mathrm{Db}$ & $65 \mathrm{Cc}$ & $92 \mathrm{Aa}$ & $73 \mathrm{Cb}$ & $41 \mathrm{Cc}$ & $89 \mathrm{Ca}$ & $67 \mathrm{Cb}$ & $31 \mathrm{Dc}$ & $82 \mathrm{Ba}$ & $54 \mathrm{Cb}$ & $7 \mathrm{Cc}$ \\
\hline Salinas 88 & $91 \mathrm{Ba}$ & $81 \mathrm{Cb}$ & $54 \mathrm{Dc}$ & $87 \mathrm{Ba}$ & $75 \mathrm{Cb}$ & $41 \mathrm{Cc}$ & $87 \mathrm{Ca}$ & $63 \mathrm{Db}$ & $32 \mathrm{Dc}$ & $76 \mathrm{Ca}$ & $48 \mathrm{Db}$ & $6 \mathrm{Cc}$ \\
\hline Everglades & $96 \mathrm{Aa}$ & $95 \mathrm{Aa}$ & $93 \mathrm{Aa}$ & $97 \mathrm{Aa}$ & $93 \mathrm{Aa}$ & $95 \mathrm{Aa}$ & $96 \mathrm{Aa}$ & $83 \mathrm{Ab}$ & $85 \mathrm{Ab}$ & $94 \mathrm{Aa}$ & $81 \mathrm{Ab}$ & $79 \mathrm{Ab}$ \\
\hline $\mathrm{CV}(\%)$ & & & & & & & & & & & & \\
\hline
\end{tabular}

Mean values followed by the same uppercase letter in the column and lowercase letter in the row do not differ among themselves by the Scott-Knott Test at 5\% probability. 


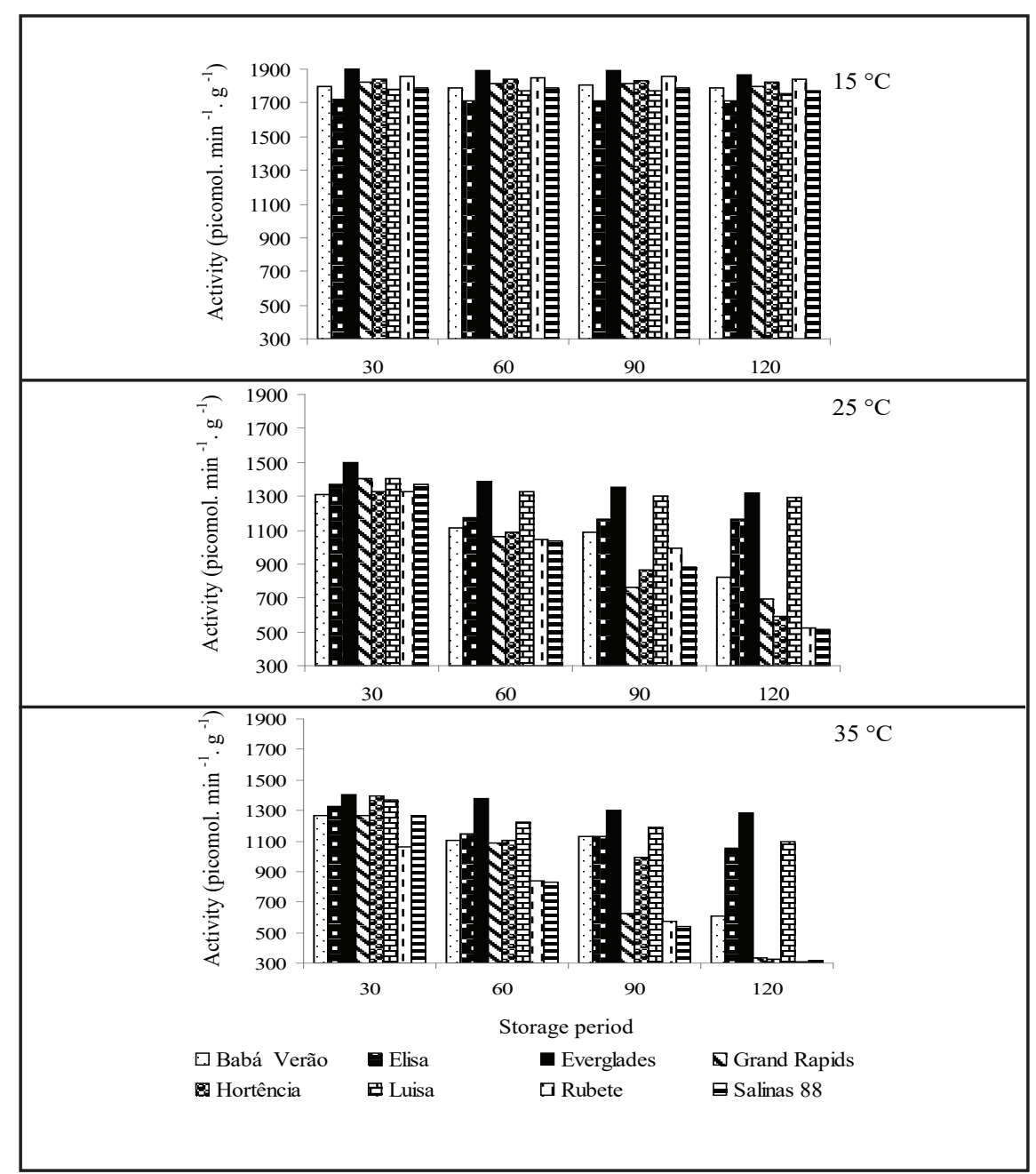

Figure 1. Activity of the enzyme endo- $\beta$-mannanase (picomol $/ \mathrm{min} / \mathrm{g}$ ) in lettuce seeds depending on ambient temperatures $\left(15 ; 25\right.$ and $\left.35^{\circ} \mathrm{C}\right)$ and storage periods $(30,60,90$ and 120 days). Lavras, UFLA, 2015.

isoforms (Silva et al., 2004). At the beginning of lettuce seeds germination, soaking results in hydration of the matrices, such as the cells of the cell wall (Nonogaki et al., 2010), composed of mannose, glucose, galactose, and arabinose, which are degraded by endo$\beta$-mannanase (Mo \& Bewley, 2003).

It was possible to observe a reduction in the activity of the enzyme endo$\beta$-mannanase throughout the storage period, especially when the lettuce seeds pre-soaked at $20^{\circ} \mathrm{C}$ were stored at 25 and $35^{\circ} \mathrm{C}$ (Figure 1), manifesting the natural process of deterioration that occurs in seeds, according to the results of germination and vigor. Other researchers observed that storage interferes in the enzyme endo- $\beta$-mananase activity of lettuce seeds (Diniz et al., 2009). The same behavior was observed for tomato seeds (Albuquerque et al., 2010). When the seeds were stored at $15^{\circ} \mathrm{C}$, there was maintenance in the activity of this enzyme, regardless of the storage period (Figure 1).

The seeds of the cultivar Everglades showed enzymatic activity of 1900 $\mathrm{pmol} / \mathrm{min} / \mathrm{g}$ when stored at $15^{\circ} \mathrm{C}$, but there was reduced activity $(1400 \mathrm{pmol} /$ $\mathrm{min} / \mathrm{g}$ ) when the seeds were stored at $35^{\circ} \mathrm{C}$. It is noteworthy that Everglades at 120 days of storage and $35^{\circ} \mathrm{C}$ also exhibited greater enzymes activity than the other cultivars. It becomes evident at high temperature that this cultivar can express its germination potential, confirming the results observed in Table 1. The result indicates the importance of the enzyme endo- $\beta$-mannanase for viability of lettuce seeds, and it is one more indication that Everglades is a thermotolerant cultivar (Catão et al., 2014). It is also fitting to note that this behavior may vary according to the species, the genotype, and the cultivar, especially when there are differences in the storage temperature.

Based on all the physiological and biochemical results discussed above, it is evident that storage temperature is fundamental in conserving the quality of lettuce seeds due to its action on viability, vigor, and the biochemical reactions that determine this entire process. There are physiological and biochemical changes in lettuce seed as a result of the storage period and the storage environment. These changes are responsible for maintaining seed quality. The cultivars respond differently to the conditions to which they were exposed. The cultivar Everglades is thermotolerant.

\section{REFERENCES}

ALBUQUERQUE, KAD; OLIVEIRA, JA; SILVA, PA; VEIGA, AD; CARVALHO, BO; ALVIM, PO. 2010. Armazenamento e qualidade de sementes de tomate enriquecidas com micronutrientes e reguladores de crescimento. Ciência e Agrotecnologia 34: 2028. DOI: $10.1590 / \mathrm{S} 1413-70542010000100002$

BARBOSA, RM; COSTA, DS; SÁ, ME. 2011. Envelhecimento acelerado em sementes de alface. Ciência Rural 41: 1899-1902. DOI: 10.1590/S0103-84782011005000138

BRASIL. 1986. Portaria $n^{\circ} 456$, de 18 de dezembro de 1986. Diário Oficial [da] República Federativa do Brasil, Brasília, 23 dez. Seção 1, p. 19653.

BRASIL. 2009. Ministério da Agricultura e Reforma Agrária. Secretaria Nacional de Defesa Agropecuária. Departamento Nacional de Produção Vegetal. Coordenação de Laboratório Vegetal. Regras para análise de sementes. Brasília, $395 \mathrm{p}$.

CARVALHO, MLM; PINHO, EVRV. 2000. Armazenamento de sementes. Lavras: UFLA, 2000. 39 p.

CATÃO, HCRM; GOMES, LAA; SANTOS, HO; GUIMARÃES, RM; FONSECA, PHF; CAIXETA, F. 2014. Aspectos fisiológicos e bioquímicos da germinação de sementes de alface em diferentes temperaturas. Pesquisa Agropecuária Brasileira 49: 316-322. DOI: 10.1590/S0100-204X2014000400010

DIAS, M; ALVES, SJ. 2008. Avaliação da viabilidade de sementes de Panicum maximum Jacq pelo teste de tetrazólio. Revista Brasileira de Sementes 30: 152-158. DOI: 10.1590/ S0101-31222008000300020

DINIZ, KA; OLIVEIRA, JA; SILVA, PA; GUIMARÃES, RM; CARVALHO, MLM. 2009. Qualidade de sementes de alface enriquecidas com micronutrientes e reguladores de crescimento durante o armazenamento. 
Revista Brasileira de Sementes 31: 228-238. DOI: 10.1590/S0101-31222009000100026

DOWNIE, B; HILHORST, HWM; BEWLEY, JD. 1994. A new assay for quantifying endo$\beta$-mananase activity using Congo Red dye. Phytochemistry 36: 829-835. DOI: 10.1016/ S0031-9422(00)90446-1

FERREIRA, RL; FORTI, VA; SILVA, VN; MELLO, SC. 2013. Temperatura inicial de germinação no desempenho de plântulas e mudas de tomate. Ciência Rural 43: 1189-1195. DOI: $10.1590 / \mathrm{S} 0103-84782013000700008$

HARRINGTON, .F. 1972. Seed storage and longevity. In Koslowski, TT (ed). Seed Biology. New York: Academic press. p.145245.

KOZAREWA, I; CANTLIFFE, DJ; NAGATA, RT; STOFFELLA, PJ. 2006. High maturation temperature of lettuce seeds during development increased ethylene production and germination at elevated temperatures. Journal of the American Society of Horticultural Science 131: 564-570. DOI: $10.1093 / \mathrm{aob} / \mathrm{mcs} 240$

MARCOS FILHO, J. 2005. Fisiologia de sementes de plantas cultivadas. Piracicaba: FEALQ. 495p.
MARTINS, L; LAGO, AA. 2008. Conservação de semente de Cedrela fissilis: teor de água da semente e temperatura do ambiente. Revista Brasileira de Sementes 30: 161-167. DOI: 10.1590/S0101-31222008000100020

MO, B; BEWLEY, JD. 2003. The relationship between b-mannosidase and endo-bmannanase activities in tomato seeds during and following germination: a comparison of seed populations and individual seeds. Journal of Experimental Botany 54: 2503-2510. DOI: $10.1093 / \mathrm{j} x \mathrm{~b} / \mathrm{erg} 274$

NASCIMENTO, WM. 2003. Preventing thermoinhibition in a thermosensitive lettuce genotype by seed imbibition at low temperature. Scientia Agricola 60: 477-480. DOI: 10.1590/S0103-90162003000300010

NASCIMENTO, WM; CANTLIFFE, DJ; HUBER, DJ. 2001. Endo-beta-mannanase activity and seed germination of thermosensitive and thermotolerant lettuce genotypes in response to seed priming. Seed Science Research 11: 255-264. DOI: 10.1590/S010390162004000200006

NASCIMENTO, WM; CRODA, MD; LOPES, ACA. 2012. Seed production, physiological quality and identification of thermotolerant lettuce genotypes. Revista Brasileira de Sementes 34: 510-517. DOI: 10.1590/ S0101-31222012000300020

NONOGAKI, H; BASSEL, GW; BEWLEY, JD. 2010. Germination still a mystery. Plant Science 179: 574-581. DOI: 10.1016/j. plantsci.2010.02.010

QUEIROZ, LAF; PINHO, EVR; OLIVEIRA, JA; FERREIRA, VF; CARVALHO, BO; BUENO, ACR. 2011. Época de colheita e secagem na qualidade de sementes de pimenta Habanero Yellow. Revista Brasileira de Sementes 33: 472-481. DOI: 10.1590/ S0101-31222011000300010

SILVA, EAA; TOOROP, PE; VAN AELST, AC; HILHORST, HW. 2004. Abscisic acid controls embryo growth potential and endosperm cap weakening during coffee (Coffea arabica) seed germination. Planta 220: 251-261. DOI: 10.1007/s00425-004-1344-0

SMITH, MT; BERJAK, P. 1995. Deteriorative changes associated with loss of viability of stored desiccation tolerant and desiccationsensitive seeds. In KIEGEL, J; GALILI, G. Seed development and germination. New York: M. Dekker. p.701-746. 